\title{
TELLING TALES: THE USE OF ORAL NARRATIVES IN RELIGIOUS SERMONS IN KENYA
}

\section{Ezekiel B. Alembi}

Religious communication uses a number of techniques or styles, for instance including films, literature, songs/poetry, and dance. In the verbal communication of a religious message, the speaker can employ proverbs, riddles, emphasis etc. An interesting development in the communication of religious messages in Kenyan churches today is the use of narratives to enhance the quality and quantity of the message.

This paper examines the use of narratives in religious communication in Kenyan Christian Churches. The paper highlights the origin of the use of the narratives, the reason for their use and the ways in which they are used.

\section{ORIGINS OF THE USE OF NARRATIVES IN SERMONS}

Christianity was introduced in Kenya by western missionaries, many of whom looked down on African traditions and practices. The early missionaries in particular attempted to ban and discourage time-tested and highly-valued African practices such as circumcision, child naming ceremonies, funeral rites and story telling. Those activities were seen as ungodly and barbaric (see for instance P'Bitek's African Religion in Western Scholarship, Mbiti's African Philosophy and Religion).

Upon gaining independence, the churches in Kenya largely came under African leadership. Since then, there has developed a blend of African and Western hymns, references are made to the Bible and African song, dance, musical instruments, proverbs and narratives are incorporated. Thus three contextual bases of narratives can be identified.

The first basis relates to the Bible, especially Jewish methods of communication, some of which were used by Jesus. The Bible has a 
collection of proverbs, riddles, parables, songs, dance and stories. These forms are used to emphasise religious truth such as the origin, fall and salvation of man.

The second source is the African background. InAfrican traditions, like the Jewish, a number of forms of communication are employed. These include riddles, proverbs, songs, dance and stories. Again, these forms do not just exist for the sake of it. They have an important role to play in transmitting information.

The third basis is contemporary life. Despite the development of communications technology, some of the old means of communication are still used. These forms have been found to be valuable in terms of precision and effectiveness, and are still drawn upon in business, politics, religion and education. In fact, there are national and global efforts to promote these forms of communication. In recent work I did for the Kenya Institute of Mass Communication, I explored folktales in population and development communication.

Churches in Kenya are not an exception in the use of narratives. They draw out a useful message using this form.

\section{WHY THESE NARRATIVES HAVE BEEN USED IN CHRISTIAN COMMUNICATION}

Narratives have a number of advantages and it is partly because of these that they enrich Christians' messages. A look at the Christian messages in which narratives are used suggest that these narratives are favoured for the following reasons.

a) They are familiar to the audience and it is easy to emphasise intended parallel lessons.

b) They are short, making it possible to pass on the message in a short period of time.

c) They are precise and effective, making it possible to identify the specific message intended.

d) They use anonymous characters with qualities which are diverse but which can be identified in the congregation. Though animal 
characters, and even human ones, are used, the intention is to give a broad as well as a specific frame of reference that the congregation can easily draw from and make specific connections with their own lives

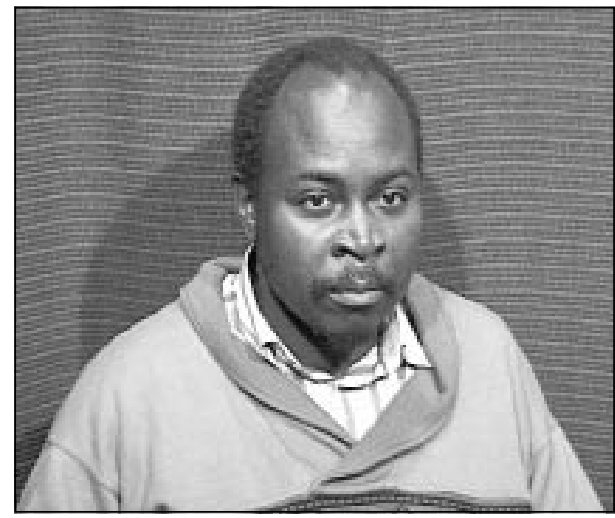
and religious convictions.

e) They make the sermon humorous but still communicate a deeper message.

f) They challenge the audience/congregation to think more deeply and draw their own conclusions and even initiate lines of action.

\section{HOW THEY HAVE BEEN USED IN RELIGIOUS COMMUNICATION}

In delivering a sermon, a church minister can combine the reading of the scripture and the explanation with a narrative. For instance, he/she can read a passage and then give a narrative, go back to the scripture and interpret it in the light of the narrative that has been used.

Alternatively, the minister can give a narrative first and then read a scripture that is closely related to the message in the narrative. $\mathrm{He} / \mathrm{she}$ therefore uses both the scriptures and narratives to explain the message.

In essence a narrative has no specific place in the presentation of the Christian message. The minister employs it as he considers appropriate at any stage of his presentation.

Below are given examples of how a Catholic priest and Protestant minister used narratives. 


\section{The Girl And The King}

Long ago there was a wealthy king who started off on a journey to visit the king of a neighbouring country. On his way he was accompanied by his bodyguard and a large group of ministers. Owing to the nature of the landscape, the only means of transport was by camel. Somewhere along the way, he found a group of girls fetching water from a well. At once he was struck by the resemblance of the girls, but on closer observation he identified one girl he had fallen in love with. He at once decided that he would do something to engage her. He gave the girl his blazer, which he instructed her to wear always as a sign of identify. He further promised that once he was back in his country, he would send for her and the emissary would identify her by her jacket.

After the king's departure, the other girls begun to envy the lucky girl and constantly begged her to let them try the blazer on, but she wouldn't budge. Days passed into weeks and the girl still faithfully kept wearing the king's coat. Over time she begun to wonder whether the king had forgotten his promise but still she kept wearing the coat.

One day she went to collect firewood in the company of the other girls. As she was moving about in the bush she saw a pirate monkey admiring her and she stopped to give it the time. The pirate greeted her and commented on the beauty of the blazer she was wearing. She immediately told the pirate the story behind her acquisition of the coat. The pirate then requested that she let him try it on so that she could see how beautiful it was.

The girl reluctantly agreed to let the pirate try the coat on and no sooner had it done so than it jumped into a tree and left the girl in wonder. The girl begun to climb the tree and the pirate jumped to the next tree. As the girl ran from tree to tree, the pirate kept jumping and soon disappeared from the girl's sight. The girl returned home miserable but consoled by the thought that after all the king had forgotten his promise.

Shortly after that incident the king sent his messengers to collect the girl and reminded them that they would find several identical girls and that they would identify the bride by a blazer bearing his seal which she would be wearing When the messengers came to the village where the girls lived they were unable to identify the one they were looking for, as all of them resembled 
one another. The particular girl tried to explain that she was the one but the messengers did not take her because she did not have the king's coat.

They searched the whole village without finding the girl and eventually gave up, and were on their way home when one of them spotted the pirate in the tree.

The messengers then ran after the pirate and managed to arrest it and take it home to the king.

This story was performed by a Catholic priest as part of his sermon. The use of this narrative at the point when it was used was very timely. For one, it illustrated the priest's sermon very well. It also awakened some members of the congregation who were beginning to fall asleep.

In his explanation, the priest said that the Jewish people's unbelief will make them miss the kingdom of God while the gentiles who believe will merit the Kingdom. He quoted extensively from Matthew 21: 33-45, Mark 12: 1-12 and Luke 20: 9-19.

He also challenged those who have received the good news and been baptised. He said that they bear the mark of Jesus and that they must struggle to remain faithful to their calling. He quoted from Mark 13: 33-37.

The Priest then recited this narrative. There was no doubt that the congregation appreciated, enjoyed and understood the narrative. The fact that they related to the message was shown by the way they exchanged smiles as the priest recited.

\section{The Old Woman And The Hyena}

The men of the village were chasing a hyena that had eaten one of the villager's lambs.

As the hyena (Linani) was running from these men with rungus, spears, bows, and arrows, saw an open old woman's house. He ran into the house and pleaded with her: "Hide me under your bed." He cried, "There are men who want to kill me!" When the men from the village reached the old woman's house they asked her, "Have you seen any hyena coming this way? She answered, "No". In haste the village men ran on. 
Once the men had gone, the hyena came out from under the bed, caught the old woman, killed and ate her.

This narrative was performed by a Protestant church minister as an introduction to his sermon on sin. Used at this point, the narrative set the congregation's mind focused on the topic of the sermon.

This is a good example of a short but precise story. It is action packed and has the ability to hook one from beginning to end. No wonder the minister used it at the point that he did. It is very relevant to the message in the sermon, as it reveals the consequences that the woman had to face as a result of hiding the hyena who symbolises sin. The hyena is destructive, as is shown in this story, in which it consumed the woman who had shielded it from death. In the same way sin, the minister explained, consumes all those Christians who hide it. The minister likened the hunters to the church ministers who are always pursuing and fighting sin and stressed that the Christians who do not share their problems, especially with those ministers, would be consumed just as the woman had.

\section{The King's Daughter and The Witch}

Once there was a king who had only one daughter. He loved her greatly and always shared meals with her. He was always hoping to prepare her to marry a man who would be capable of taking over leadership after him.

In the same village, there was a witch who envied the king's daughter and always looked for an opportunity to destroy her. One day she crept into the king's house through the window after the King and his daughter's breakfast table had been laid. She put poisonous herbs into the young girl's tea and crept out. When the young girl took the tea, she turned into a frog through the effect of the poisonous herbs. The "frog" then began hopping, and it moved out of the house and into the bush. It began another life of wandering as it looked hopefully for some help. Hopping in the jungle in this way, it reached another country far from the girl's original country.

In that far away country there was a chief who had one son. The King's son loved hunting for sport and often went with guards into the forest on hunting expeditions. One day he went into the 
forest, and as he was wandering he saw a frog hopping around him. The frog struck him and attracted his attention, and he picked it and put it in his pocket. When he got back home, his father inquired about his hunting achievements that day. The son said that he hadn't killed any game but produced a frog from his pocket, explaining that it was the only thing he had brought home. The father was very disappointed and reprimanded his son for his lack of skill. He then ordered him to throw away the frog. The young man was very disappointed at his father's reaction and withdrew into his bedroom to contemplate his next step. While in his room, he removed the frog from his pocket and began to admire it.

Then the frog spoke to him and said - "Please do not throw me away into the lonely jungle - put me under your warm pillow and I shall reward you." The young man obeyed the frog's words and went to sleep with it-under the pillow. On the following morning, he woke up to find himself lying beside a young beautiful girl - the frog had turned back to its original state - a girl.

The girl spoke to the young man and explained her predicament to him, then she offered to take the young man to her own country to introduce him to her father. When the boy's father saw the girl, he was very impressed and allowed his son to accompany her to her house. Upon reaching the girl's home, the boy was welcomed by the girl's father and as a reward for what he had done he was permitted to marry the girl - and also given the whole of her father's kingdom. He therefore became king of his own country and joined it to his wife's country-and they lived happily ever after.

“The King's Daughter and the Witch" was performed by a Catholic priest. He used it to illustrate the history of the salvation of man.

. Quoting from Genesis 1: 26ff., the priest reminded the congregation that man was created in the image and likeness of God, and that man was given all the privileges that God himself enjoys. However, the devil (who in the narrative is represented by the witch), was jealous of man and bewitched him (Genesis 3) so that man lost his status and became like a wandering frog. Man had to suffer exile and a life of sin (likened to darkness). 
The priest told the congregation that God loved the world so much that He had sent His son Jesus Christ to die so that humanity may survive, and that Jesus transformed human beings and reinstated them to their original state and the devil (the witch) has no more power over them. The young man in the story symbolises the sacrifice Jesus made - loving the sinner regardless of how evil and dirty he was.

The priest also told the congregation that this narrative parallels the story of Jesus' healings - especially in those cases where he healed people with leprosy. These were people who were unacceptable in society and who were required by law to alert "normal" or "clean" people by ringing bells to say that they were around. Touching a frog and putting it in the pocket can be likened to touching a leper and showing him love. He quoted extensively from Matthew 8: 1-4; Luke 5: 12-16 and Mark 1: 40-45. "The gratitude of the girl in the story is similar to the way the man cured of leprosy went about spreading his experience to those who cared to hear," he said.

\section{CONCLUSION}

Narratives can be used to convey a general and also specific message. As shown in the case of Christian communication in Kenya, narratives are used to reinforce Biblical messages. These narratives are favoured because of their familiarity with the congregation, their humour and the fact that they provide general and specific references. 